\title{
People living with Human Immunodeficiency Virus on anti-retroviral therapy are increasing: Effective patient retention strategy is need of the hour in low and middle-income countries
}

Sir,

Human Immunodeficiency Virus (HIV) infection and Acquired Immunodeficiency Syndrome (AIDS) remain as an important cause of global burden of disease. ${ }^{[1]}$ The prevalence of HIV infection that is, people living with HIV/ADIS (PLH/PLA/ PLHA) are globally increasing. According to the recent estimate, about 35 million people were living with HIV throughout the globe. ${ }^{[2]}$ Although the prevalence is increasing, it is certainly evident that the number of new HIV infections were significantly declined.

In the recent past, the increase of HIV prevalence is mainly attributed to the prevention of AIDS-related deaths by an effective anti-retroviral therapy (ART), which increases the lifespan of PLHA by immune restoration or preservation. Reportedly about 7.6 million cases of AIDS-related deaths were averted by ART between 1995 and 2013. ${ }^{[2]}$ Furthermore, occurrence of persistent new HIV infections add up to the existing cases increases the PLH throughout the globe.

Although ART increases the lifespan of PLH, it does not cure from HIV infection and the strategy of lifelong therapy continues. ${ }^{[3]}$ Further, as the PLH increases, PLH on ART also increases - As on 2013, it is estimated that about 11.7 million people were registered for ART in low- and middle-income countries and it is projected to reach 15 million by 2015. Further, the implementation of World Health Organization (WHO) 2013 treatment guidelines would further escalates this number to 25.9 million (estimated) in low- and middle-income countries alone, which possess major challenge in patient retention. According to recent WHO report, ${ }^{[4]}$ the patient retention rate gradually decrease to $86 \%$ after 1 -year, $82 \%$ after 2 years and only $72 \%$ after 5 years, especially in low- and middle-income countries. As the drop out cases may result in the emergence and dissemination of drug-resistant HIV strains, we are in the urgent need to construct an effective policy to retain all or at least $90 \%$ of PLH on ART in low- and middle-income countries. Therefore, the implementation of WHO 2013 HIV treatment guidelines could be considered after implementing an effective patient retention strategy with the assurance of availability and accessibility of ART drugs to all HIV-infected patients without any interruption.

\section{Ramalingam Sekar, Murugesan Amudhan, Manoharan Mythreyee}

Department of Microbiology, Faculty of Medicine, Government Theni Medical College, The Tamil Nadu Dr MGR Medical University, Theni, Tamil Nadu, India

Address for Correspondence: Ramalingam Sekar, Department of Microbiology, Government Theni Medical College, Theni - 625 512, Tamil Nadu, India.

E-mail: sekaralingam@gmail.com

\section{REFERENCES}

1. Murray CJ, Ortblad KF, Guinovart C, Lim SS, Wolock TM, Roberts DA, et al. Global, regional, and national incidence and mortality for HIV, tuberculosis, and malaria during 1990-2013: A systematic analysis for the Global Burden of Disease Study 2013. Lancet 2014;384:1005-70.

2. UNAIDS. The Gap Report. Joint United Nations Programme on HIV/AIDS, 2014. Available from: http://www.unaids.org/sites/default/files/en/media/ unaids/contentassets/documents/unaidspublication/2014/UNAIDS_Gap_ report_en.pdf. [Last accessed on 2015 Jul 3].

3. Maartens G, Celum C, Lewin SR. HIV infection: Epidemiology pathogenesis, treatment, and prevention. Lancet 2014;384:258-71.

4. WHO.GlobalUpdateonHIVTreatment.WorldHealthOrganization;2013.Available from: http://apps.who.int/iris/bitstream/10665/85326/1/9789241505734_eng pdf. [Last accessed on $2015 \mathrm{Jul} 3]$.

This is an open access article distributed under the terms of the Creative Commons Attribution-NonCommercial-ShareAlike 3.0 License, which allows others to remix, tweak, and build upon the work non-commercially, as long as the author is credited and the new creations are licensed under the identical terms.

\begin{tabular}{|l|l|}
\hline \multicolumn{2}{|l|}{ Access this article online } \\
\hline Quick Response Code: & $\begin{array}{l}\text { Website: } \\
\text { www.ijmedph.org }\end{array}$ \\
\hline & \\
\cline { 2 - 2 } & \\
\hline
\end{tabular}

How to cite this article: Sekar R, Amudhan M, Mythreyee M. People living with Human Immunodeficiency Virus on anti-retroviral therapy are increasing: Effective patient retention strategy is need of the hour in low and middle-income countries. Int $\mathrm{J}$ Med Public Health 2015;5:396. 